\title{
Relationship between Somatic Cell Count and Bovine Subclinical Mastitis in Raw Milk in Egypt
}

\author{
Amira Helmy, Ahmed El-Gamal ** . Mohammed Elsherbini* \\ * Food Hygiene and Control Department, Faculty of Veterinary Medicine, Mansoura University. \\ **Animal Health and Research Institute. Mansoura branc
}

\section{KEYWORDS:}

Raw milk; cow; buffaloe; subclinical mastitis; Somatic Cell Count, microbiological analysis.
*Corresponding author:

Mohammed Elsherbini

Mobile: 01006268960

E-Mail: mohamedsherpiny43@yahoo.com
A total of 150 raw milk samples (75 each from Holstein Friesian cows and 75 buffaloes)from Egyptian farms were collected and transferredto the Laboratory to estimate Somatic Cell Count and bacteriological examination for diagnosis of subclinical mastitis. Prevalence of S.aureus, Staphyloccocus spp., Streptococcus agalactiae and Streptococcus spp. in cow milk samples were $60.0 \%, 34.7 \%, 17.3 \%$ and $54.7 \%$ respectively; the prevalence of the corresponding bacterial species in buffaloes were $48.0 \%$, $32.0 \%, 10.7 \%$ and $50.7 \%$, respectively. On the other hand, prevalence of E.coli, Klebsiella, Proteus, Morganella, Providencia and Citrobacter in were $18.7 \%, 45.3 \%, 73.3 \%, 24.0 \%, 30.7 \%$ and $1.4 \%$ in cows milk samples, and $14.7 \%, 70.7 \%, 76.0 \%, 49.5 \%$, $56.0 \%$ and $2.6 \%$ in buffaloes milk, respectively. Milk samples contained SCC lower than $200000 \mathrm{SCC} / \mathrm{ml}$ were mostly culture negative. Samples having 200 000- 500000 of SCC/ml were mainly infected with Enterobactericeae spp. Samples with high SCC (500 000 to $1000000 / \mathrm{ml}$ ) was associated with infections caused by most studied bacteria especially S.aureus $(54.3 \%)$, whereas samples with very high SCC $(\geq 1000000) / \mathrm{ml})$ was associated with infections caused by Staphylococcus spp (62.0\%), Streptococcus agalactiae(73.0\%), S.aureus(43.2\%), Streptococcus spp(53.1\%), E.coli(43.0\%), Klebsiella(45.9\%), Proteus $(40.9 \%)$, Morganella (56.4\%), Providencia $(47.7 \%)$ and Citrobacter (66.7\%). The present study concluded that most of milk samples analyzed contained high bacterial and SCC , therefore attention should be directed towards the health status of the bovine udder and the appropriate measures to minimize the incidence of mastitis . 


\section{Introduction}

Mastitis remains to be the most important costly disease of dairy cows (19)which is originated by anextensive spectrum of pathogenic agents that invade the teat canal and proliferate in the udder cistern (13), pathogens include Staphylococcus aureus, Streptococcus agalactiae, Corynbacteriumbovis and Mycoplasma spp. or environmental pathogens include Escherichia coli, Enterococcus faecalis, Streptococcus dysagalactiae and, Streptococcus uberis and Coagulase-Negative Staphylococci (CNS) (22). Mastitis can harmfully change the quality of milk and profitable efficiency of farms (41) as the bacterial infection of milk from the diseased cows makes it unfit for human consumption and has zoonotic significance (33). In the dairy industry, both clinical and subclinical mastitis cause great economic losses (1). About 70 to $80 \%$ of the estimated $\$ 140$ to $\$ 300$ loss per cow per year from mastitis belong to low milk production caused by in apparent signs subclinical mastitis (24). Subclinical mastitis is not easy to be diagnosed due to the nonappearance of any clinical symptoms also requires the facilities of a rapid screening test for early onset disease detection (39). Different methods of diagnosis of SCM have been set up including evaluation of SCC which is an evidence of inflammation. Food safety regulations in European countries , Australia, and New Zealand mentioned that SCC more than 400000 cells $/ \mathrm{ml}$ milk is un fit for human consumption, the USA above 750000 cells $/ \mathrm{ml}$ milk and Canada and
South Africa 500000 cells $/ \mathrm{ml}$ milk .As a result, dairy producers have responsibility make sure that milk SCC formed by own herd is constantly at lowest permitted ratio and hence meets the qualification levelsin force (20). In Kosovo, Bytyqi et al. (12) showed that the bacterial infection can cause Somatic Cell Count (SCC) as high as above $1 \times 10^{6}$ cells $/ \mathrm{ml}$, and they mentioned that the contagious bacteria (Staphylococcus aureus, Streptococcus agalactiae) generally cause the highest SCC elevation while considerably less SCC in case of the environmental bacteria Streptococcus dysgalactiae, Streptococcus Uberis, Corynebacterium Spp., as well as Coagulase Negative Staphylococcus (CNS). Therefore Somatic Cell Count (SCC) is still an important means to distinguish between healthy and infected animal (5). In addition to SCC estimation, the bacteriological examination of milk samples served as a gold standard method for estimation of different tests used for diagnosis of SCM and evaluation of intramammary infection (26).

The purpose of the present study is to evaluate the correlation between SCC and investigating the occurrenceof some subclinical and to discuss the public health importance of subclinical mastitis and its control in dairy farm.

\section{Materials and Methods}

\section{1.Animals:}

A number of 75 clinicallyhealthy milkproducing cows of Holstein Friesian breed in special dairy farm and 75 buffaloes fromprivate owners were used for milk sampling in Dakahlia governorate, Egypt. 


\subsection{Collection of milk samples :}

Sampling of milk was carried out as previously described (31). Milk samples were obtained from the dairy cows and buffaloes before morning milking. All animals had no symptoms of clinical mastitis at the time of collection. Teat orifices were cleaned and swabbed by apiece of cotton immersed in $70 \%$ ethyl alcohol. The first amount of foremilk was discarded; then $50 \mathrm{ml}$ of milk was obtained aseptically from each animal into sterile test tubes. Milk samples were reserved cold during transportation at $4^{\circ} \mathrm{C}$ and reached to the laboratory to be examined within 2 hours after collection. Each sample was agitated thoroughly before being divided into two parts. The first part was used for cytological examination, while the second was served for bacteriological examinations

\subsection{Detection of subclinical mastitis:}

\subsubsection{Somatic cell count (SCC) :}

Collected milk samples were tested for SCC automatically by a Bentley Soma count, 150 (Bentley, U.S.A) as previously described (42). The sample was warmed in a water bath at $40^{\circ} \mathrm{C}$ for 5 minutes then mixed automatically before automatic evaluation of SCC by Bentley Soma count 150 for dispersion of fat globules. Somatic Cell Count (SCC) indicates the number of white blood cells (which is consisting of macrophages, neutrophils, eosinophils, lymphocytes), and numerous epithelial cell types of the mammary gland in milk that were existing in a large number in case of subclinical mastitis.

\subsubsection{Bacteriological examination of milk samples:}

From milk samples, $10 \quad \mu l \quad$ were inoculated onto Mannitol salt agar, blood agar, Edward's media and MacConkey agar plates according to (26). Plates were incubated aerobically at $37^{\circ} \mathrm{C}$ for $24-48$ h. After that, the plates were examined for colonial morphology, hemolytic characteristics, and pigmentation at 2448h. Presumptive identification of bacterial isolates was determined according to their colonial characteristics, Gram's reaction and morphology. Identification was confirmed by additional laboratory tests ( 3 , 29,30 ).

\section{Results and Discussion}

Milk remains to be one of the most essential foods of human beings. Because of its necessary components, it is internationally known as a complete diet. However, mastitis decreases the value of milk and is one of the most frequent and expensive disease of dairy industry (8). In addition to that, it is multi-factorial and a complex disease, the occurrence of which depends on variables related to the animal, environment and pathogen (28). The inflammatory response increases Somatic Cell Count (SCC) in milk. Somatic Cells are very specific, and are only elevated in the mammary once infection occurred (38).

\section{1. prevalence rate of microorganisms isolated from subclinical mastitis milk samples of dairy cows and buffaloes}

There was an increase in bacterial isolation frequency of $S$. aureus, Staphylococcus spp., Streptococcus agalactiae, Streptococcus spp., and E.coli 
from cows milk in comparison with that from buffaloes milk. Conversely, there was an increase in bacterial isolation frequency of Proteus, Citrobacter and others microorganism from buffaloes milk in comparison with that from cows milk.

Results summarized in Table mentioned that causative agents implicated in subclinical mastitis and their frequency of isolation in examined milk samples. Proteus, S. aureus, Streptococcus spp. and Klebsiella were the most prevalent microorganisms in cows milk, where they were detected at high percentages of $73.3 \%, \quad 60 \%, \quad 54.7 \%$ and $45.3 \%$ respectively. In this respect, Sudhan et al. (37) investigated the microbial isolates of subclinical mastitis in cows milk and showed that $S$. aureus was the major bacteria $(56.8 \%)$ followed by Micrococcus spp. (15.5\%), Klebsiella (3.4\%), and E. coli $(1.7 \%)$. In addition, Abdel-Rady et al. in Egypt (2), Ayano et al. in Ethiopia (9), Elango et al.in India (15), Hameed et al. in Poland (18) and Shrestha et al. in Nepal (35) reported nearly similar prevalence rates for $S$. aureus, Staphylococcus spp. and Streptococcus spp .in subclinical mastitic cows milk samples.

On the other hand, proteus, klebsiella, providencia, Streptococcus spp., Morganella and S. aureus were the most prevalent microorganisms in buffaloes milk; Where they were detected at high percentages of $76 \%, 70.7 \%, 56 \%, 50.7 \%$, $49.5 \%$ and $48 \%$ respectively. The prevalence rates of $S$. aureus and Streptococcus spp., in the present study are in agreement with those reported previously $(4,6,36)$.

Our results (table 1) also revealed significant differences $(\mathrm{p}<0.05)$ in the numbers of samples positive for klebsiella, Morganella and providencia between cows and buffaloes milk.

\subsection{Correlation between bacterial species and SCC $\times\left(10^{5} / \mathrm{ml}\right)$ in raw milk samples}

Somatic Cell Count was assessed in correlation with the type of bacterial isolates from the examined subclinical milk samples of cows and buffaloes. Generally, there are a positive correlation between the microbial populations and Somatic Cell Count. As the microbial population increased, the somatic cell counts increased. The results presented in Table (2) showed that milk samples had level of SCC lower than 200000 were mainly associated with low microbial population.

Nonetheless, Samples that contained 200 000- 500000 of SCC/ml were mainly infected with enterobactericeae spp. High SCC of $500 \quad 000-1000 \quad 000 / \mathrm{ml}$ was associated with high contamination with the most bacterial species isolated especially $S$. aureus (54.3\% amongst all isolates).

Much higher SCC ( $\geq 1000$ 000)/ml) was associated with higher microbial populations especially Streptococcus agalactiae(73.0\%), followed by Citrobacter $(66.7 \%)$ and Staphylococcus spp. (62.0\%). These results are in agreement with $(12,17,40)$, who concluded that the contagious pathogenic 
agents (Streptococcus agalactiae and S.aureus) mainly produce the greatest SCC rise, while considerably less SCC in case of the environmental pathogenic agents (Streptococcus dysgalactiae, Coagulase Negative Staphylococcus (CNS), Streptococcus Uberis also Corynebacterium spp.).

\subsection{The influence of different microbial} species on Somatic cell count $(\mathrm{SCC} \times$ $10^{5} / \mathrm{ml}$ ) in subclinical mastitic milk of cows and buffaloes

Somatic Cell Count is an important method for estimation of subclinical mastitis and milk value. The normal count of SCC in milk should not be more than 200000 cells $/ \mathrm{ml}$. Higher SCC indicates udder infections; moreover high SCC causes a rise in whey protein and a decrease in casein, leading to a considerable lower cheese yields. In addition, shorter shelf life and adverse milk flavor are other consequences of high SCC (10).
Results summarized in Table (3) revealed that when Streptococcus agalactiae, S.aureus, Staphylococcus spp., Streptococcus spp., E. coli, Morganella and providencia were detected as predominant species, the SCC (x 10 $/ \mathrm{ml})$ showed significant $(\mathrm{p}<0.05)$ increases in buffaloes milk in comparison with cows milk.

On the other hand, when Klebsiella, Proteus, Morganella, and Citrobacter were the predominant microorganisms, higher significant increases $(\mathrm{p}<0.001)$ in $\operatorname{SCC}(x$ $10^{5} / \mathrm{ml}$ ) were detected in buffaloes milk versus cows milk.

It has been indicated that buffaloes had higher absolute and relative resistance to subclinical mastitis (25), and hence buffaloes showed high levels of $\mathrm{MSCC} / \mathrm{ml}$ in raw milk samples in case of subclinical mastitis $(14,27,32)$. Conversely, other researches revealed that there were higher values of $\mathrm{SCC} / \mathrm{ml}$ for SCM milk samples of cows $(7,11,21)$.

Table 1: prevalence rate of microorganisms isolated from subclinical mastitis milk samples of dairy cows and buffaloes

\begin{tabular}{|l|c|c|c|c|c|}
\hline \multirow{2}{*}{ Microorganism } & \multicolumn{2}{|c|}{ Cows $(\mathbf{n}=\mathbf{7 5})$} & \multicolumn{2}{c|}{ Buffalos(n= 75) } & \multirow{2}{*}{ P value; $\mathbf{X}^{\mathbf{2}}$} \\
\cline { 2 - 5 } & Present & $\mathbf{\%}$ & Present & $\mathbf{\%}$ & \\
\hline S. aureus & 45 & $60.0 \%$ & 36 & $48.0 \%$ & $2.17 ; 0.14(\mathrm{NS})$ \\
\hline Staphylococcus spp. & 26 & $34.7 \%$ & 24 & $32.0 \%$ & $0.12 ; 0.73(\mathrm{NS})$ \\
\hline Streptococcus agalactiae & 13 & $17.3 \%$ & 8 & $10.7 \%$ & $1.38 ; 0.24(\mathrm{NS})$ \\
\hline Streptococcus spp. & 41 & $54.7 \%$ & 38 & $50.7 \%$ & $0.24 ; 0.62(\mathrm{NS})$ \\
\hline E. coli & 14 & $18.7 \%$ & 11 & $14.7 \%$ & $0.43 ; 0.51(\mathrm{NS})$ \\
\hline Klebsiella & 34 & $45.3 \%$ & 53 & $70.7 \%$ & $9.88 ; 0.002 *(\mathrm{~S})$ \\
\hline Proteus & 55 & $73.3 \%$ & 57 & $76.0 \%$ & $0.14 ; 0.71(\mathrm{NS})$ \\
\hline Morganella & 18 & $24.0 \%$ & 37 & $49.5 \%$ & $10.36 ; 0.001 *(\mathrm{~S})$ \\
\hline Providencia & 23 & $30.7 \%$ & 42 & $56.0 \%$ & $9.80 ; 0.002 *(\mathrm{~S})$ \\
\hline Citrobacter & 1 & $1.4 \%$ & 2 & $2.6 \%$ & $0.32 ; 0.57(\mathrm{NS})$ \\
\hline Others Microorganism & 69 & $92.0 \%$ & 70 & $93.3 \%$ & $0.09 ; 0.75(\mathrm{NS})$ \\
\hline
\end{tabular}

(NS) : Non Significant

(S): Significant 
Table (2): Correlation between bacterial species and SCC $x\left(10^{5} / \mathrm{ml}\right)$ in raw milk samples

\begin{tabular}{|l|c|c|c|c|c|}
\hline \multirow{2}{*}{ microorganism species } & \multicolumn{5}{|c|}{ SCC $\mathbf{~ ( 1 0} / \mathbf{m l})$ range } \\
\cline { 2 - 6 } & $\mathbf{S 2}$ & $\mathbf{2 - 5}$ & $\mathbf{5}-\mathbf{1 0}$ & $\mathbf{1 0}$ & total \\
\hline S. aureus & $0.2 \%$ & $2.2 \%$ & $54.3 \%$ & $43.2 \%$ & $100.0 \%$ \\
\hline Staphylococcus spp. & $1.0 \%$ & $3.0 \%$ & $34.0 \%$ & $62.0 \%$ & $100.0 \%$ \\
\hline Streptococcus agalactiae & $1.2 \%$ & $2.0 \%$ & $23.8 \%$ & $73.0 \%$ & $100.0 \%$ \\
\hline Streptococcus spp. & $1.3 \%$ & $1.3 \%$ & $44.3 \%$ & $53.1 \%$ & $100.0 \%$ \\
\hline E.coli & $1.0 \%$ & $4.0 \%$ & $52.0 \%$ & $43.0 \%$ & $100.0 \%$ \\
\hline Klebsiella & $2.3 \%$ & $4.6 \%$ & $47.2 \%$ & $45.9 \%$ & $100.0 \%$ \\
\hline Proteus & $5.4 \%$ & $9.8 \%$ & $43.9 \%$ & $40.9 \%$ & $100.0 \%$ \\
\hline Morganella & $1.8 \%$ & $3.6 \%$ & $38.2 \%$ & $56.4 \%$ & $100.0 \%$ \\
\hline Providencia & $3.1 \%$ & $9.2 \%$ & $40.0 \%$ & $47.7 \%$ & $100.0 \%$ \\
\hline Citrobacter & $0.0 \%$ & $0.0 \%$ & $33.3 \%$ & $66.7 \%$ & $100.0 \%$ \\
\hline Others Microorganism & $2.9 \%$ & $3.6 \%$ & $41.0 \%$ & $52.5 \%$ & $100.0 \%$ \\
\hline
\end{tabular}

$\%$ : indicates the percentages of certain bacterial species amongst all isolates detected

Table (3): The influence of different microbial species on Somatic cell count ( $\mathrm{SCC} \times 10^{5} / \mathrm{ml}$ ) in subclinical mastitic milk of cows and buffaloes

\begin{tabular}{|c|c|c|c|c|c|c|c|}
\hline \multirow[t]{2}{*}{ Microorganism } & \multicolumn{3}{|c|}{$\begin{array}{c}\operatorname{SCC} \times\left(10^{5} / \mathrm{ml}^{\prime}\right) \text { in Cows } \\
(\mathrm{n}=75)\end{array}$} & \multicolumn{3}{|c|}{$\begin{array}{c}\operatorname{SCC} \times\left(10^{5} / \mathrm{ml}\right) \text { in Buffalos } \\
(n=75)\end{array}$} & \multirow[t]{2}{*}{$P$ value } \\
\hline & Min & $\operatorname{Max}$ & Mean \pm SD & Min & Max & Mean \pm SD & \\
\hline S. aureus & 6.7 & 17.8 & $9.88 \pm 2.07$ & 7.1 & 19.0 & $11.38 \pm 3.96$ & $<0.05$ \\
\hline Staphylococcus spp. & 5.2 & 16.0 & $10.10 \pm 2.46$ & 5.9 & 19.0 & $12.55 \pm 3.73$ & $<0.05$ \\
\hline $\begin{array}{l}\text { Streptococcus } \\
\text { agalactiae }\end{array}$ & 6.50 & 18.2 & $10.45 \pm 2.78$ & 7.1 & 18.7 & $12.81 \pm 2.82$ & 5 \\
\hline Streptococcus spp. & 4.90 & 15.8 & $9.70 \pm 2.60$ & 3.8 & 16.2 & $11.43 \pm 3.92$ & $<0.05$ \\
\hline E. coli & 5.0 & 13.6 & $8.39 \pm 3.74$ & 6.1 & 14.3 & $11.15 \pm 4.38$ & $<0.05$ \\
\hline Klebsiella & 3.3 & 12.8 & $8.54 \pm 3.78$ & 4.2 & 17.0 & $10.57 \pm 3.69$ & $<0.001$ \\
\hline Proteus & 4.1 & 14.9 & $9.11 \pm 2.65$ & 4.6 & 17.2 & $9.95 \pm 4.23$ & $<0.0001$ \\
\hline Morganella & 5.0 & 12.0 & $8.57 \pm 2.09$ & 3.7 & 18.0 & $10.04 \pm 3.36$ & $<0.05$ \\
\hline Providencia & 4.4 & 16.0 & $9.21 \pm 5.01$ & 3.8 & 16.7 & $11.05 \pm 3.62$ & $<0.05$ \\
\hline Citrobacter & 5.3 & 10.0 & $8.00 \pm 2.04$ & 7.20 & 12.00 & $11.10 \pm 2.04$ & $<0.0001$ \\
\hline Others Microorganism & 2.2 & 19.0 & $8.81 \pm 2.97$ & 2.8 & 19.0 & $10.30 \pm 3.88$ & $<0.01$ \\
\hline
\end{tabular}

\section{Conclusion}

The present study concluded that estimation of Somatic Cell Count in addition to identification of the causative microorganisms are very important tools that can be used for evaluation of subclinical mastitis (SCM); in addition, there is a strong correlation between SCM and elevation of SCC in raw milk. So, attention should be directed towards the status of health of the bovine udder and the appropriate measures applying to minimize the incidence of mastitis and eliminate the reservoir of the disease.

\section{References}

1- Abd Ellah, M. R. (2013): Role of Free Radicals and Antioxidants in Mastitis. Journal of Advanced Veterinary Research, 3(1), 1-7.

2- Abdel-Rady, A. and Sayed, M. (2009): Epidemiological Studies on Subclinical Mastitis in Dairy cows in Assiut Governorate. Vet. World, 2(10): 373380.

3- Abera, M.; Demie, B.; Aragaw, K.; Regassa, F. and Regassa, A. (2010): Isolation and identification of 
Staphylococcus aureus from bovine mastitic milk and their drug resistance patterns in Adama town, Ethiopia. J. Vet. Med. Anim. Hlth., 2(3): 29-34.

4- Ahmad S. I. Gaucher, F. Rousseau, E. Beaucher, M. Piot, J. F. Grongnet and F. Gaucheron (2008): Effects of acidification on physicochemical characteristics of buffalo milk: A comparison with cow's milk. Food Chem. 106:11-17.

5- Akerstedt, M. (2008): Bovine Acute Phase Proteins in Milk Haptoglobin and Serum Amyloid A as Potential Biomarkers for Milk Quality. Doctor's dissertation.

6- Aliaa A. E. M.; Ahlam K. A. W.; Ragaa A. S. R. f. and Yousreya, H. M. (2013): Some bacteriological and biochemical studies on subclinical mastitis in buffaloes. New York. Sci J 6(7): 71-79.

7- Angy, A. F. A. A. (2013): Importance of Somatic Cell Count and California Mastitis in detecting subclinical mastitis in dairy cow. M.V.Sc., Thesis, milk hygiene, Faculty of Vet. Med. Zagazig Univ.

8- Awale MM, Dudhatra GB, Avinash K, Chauhan BN, Kamani DR, Modi CM, Patel HB, O'Kennedy(2012): Bovine mastitis: a threat to economy. Open Access Scientific Reports; Vol. 1: 295-303.

9- Ayano, A.; Hiriko, F.; Simyalew, A. and Yohannes, A. (2013): Prevalence of subclinical mastitis in lactating cows in selected commercial dairy farms of Holeta district. Journal of Veterinary Medicine and Animal Health., 5(3):67-72.
10- Bilal, M. Q. and Ahmed, A. (2004): Daily Hygiene and Disease Prevention. Usman and Bilal Printing Linkers, Faisalabad, Pakistan.

11- Branko, A.; Ljupco, M.; Ljupco, A.; Martin, N.; Marija, R.; Dean, J. and Toni, D. (2012): Implementation of strategies for mastitis control in dairy herds in Macedonia: a case report. Macedonian Veterinary Review., 35(2): 87-90.

12-Bytyqi H, Zaugg U, Sherifi K, Hamidi A, Gjonbalaj M, Muji S and Mehmeti H.(2010): Influence of management and physiological factors on Somatic Cell Count in raw milk in Kosova. VeterinarskiArchiv. 80(2): 173-183.

13-Calvinho, L.F., \&Tirante, L. (2005): Prevalencia de microorganismos patógenos de mastitis bovina $y$ evolución del estado de salud de la glándulamamaria en Argentina en los últimos 25 años. Revista FAVE 4(12):29-40.

14- Dhakal, I. P. (2006): Normal Somatic Cell Count and subclinical mastitis in Murrah buffaloes. Journal of Veterinary Medicine, Series B., 53(2): 81-86.

15- Elango, A.; Doraisamy, K.A.; Rajarajan, G. and Kumaresan, G. (2010): Bacteriology of subclinical mastitis and antibiogram of isolates recovered from cross bred cows. Ind. J. Anim.Res., 44(4): 280-284.

16- Elbably, M.A.; Emeash, H.H. and Asmaa, N.M. (2013): Risk factors associated with mastitis occurrence in dairy herds in Beni-Suef Govemorate. World's Vet. J., 3(1): 5-10. 
17- Green M.J., Green L.E., Bradley A.J., Burton P.R., Schukken Y.H., Medley G.F.(2005): Prevalence and associations between bacterial isolates from dry mammary glands of dairy cows. Vet Rec, 156, 71- 77.

18- Hameed JC. A.; Sender, G. andTCorwjn-JCossakowska, A. (2006): Public health hazard due to mastitis in dairy cows. Animal Science Papers and Reports., 25(2): 73-85.

19- Hillerton J.E., Barry E.A.(2005): Treating mastitis in the cow - a tradition or an archaism. J Appl Microbiol, 98, 1250-1255.

20- International Dairy Federation. (1997): Recommendations for Presentation of Mastitis-Related Data. Bulletin No. 321/1997'. International Dairy Federation, Brussels, Belgium, 36 pages.

21- Kamal, R. M.; Bayou mi, M. A. and Abd El Aal, S. F. A. (2014): Correlation between some direct and indirect tests for screen detection of subclinical mastitis. International Food Research Journal, 21(3): 1213-1218.

22- Keane, O. M.; Budd, K. E.; Flynn, J. and McCoy, F. (2013): Pathogen profile of clinical mastitis in Irish milk recording herds reveals a complex aetiology. The Veterinary Record., 173(1): 17.

23- Lehtolainen T., PohjanvirtaPyörälä S. and Pelkonen S.(2003): Association between Virulence Factors and Clinical Course of Escherichia coli Mastitis. Acta vet. Scand; Vol.44: 203-205.

24- Leitner, G., Merin, U., \&Silanikove, N. (2011): Effects of glandular bacterial infection and stage of lactation on milk clotting parameters: Comparison among cows, goats and sheep. International Dairy Journal., 21(4): 279-285. Letters. 16(3): 62096217.

25- Moroni, P.; Rossi, C. S.; Pisoni, G.; Bronzo, V.; Castiglioni, B. and Boettcher, P. J. (2006): Relationships between somatic cell count and intra mammary infection in buffaloes. Journal of dairy science., 89(3): 9981003.

26- National Mastitis Council, (1999): Microbiological Procedures for the Diagnosis of Bovine Udder Infection. National Mastitis Council. 3rd ed. Arlington, Virginia, USA.

27- Oezenc, E.; Vural, M. R.; Scker, E. and Ucar, M. (2008): An evaluation of subclinical mastitis during lactation in Anatolian buffaloes. Turkish Journal of Veterinary and Animal Sciences., 32(5): 359-368.

28- Ondiek O., Ogore P., Shakala, E., and Kaburu, G.(2013):Prevalence of bovine mastitis, its therapeutics and control in Tatton Agriculture Park, Egerton University, Njoro District of Kenya. Basic Research Journal of Agricultural Science and Review; Vol. 2(1):15-20.

29- Persson, Y.; Nyman, A.K.J. and Andersson, U.G. (2011): Etiology and antimicrobial susceptibility of udder pathogens from cases of subclinical mastitis in dairy cows in Sweden. ActaVeterinariaScandinavica, 53: 36-43.

30- Quinn, P.J.; Carter, M.E.; Markey, B. and Carter, G.R. (1994): Clinical 
Veterinary Microbiology, Wilfe Publishing, London pp. 95-101.

31- Radostits, O.M.; Gay, c.c.; Hinchcliff, W.k. and Constable, P.D.(2007): veterinary Medicine, A textbook of the disease of cattle, horse, sheep, pigs and goats. Saunders pub. Tenth edition, 314-325.

32- Sharif, A. and Ahmad, T. (2007): Prevalence of severity of mastitis in buffaloes in district Faisalabad (Pakistan). J. Agric. Soc. Sci., 3(4): 34-36.

33- Sharif, A., Umer, M. U. H. A. M. M. A. D., and Muhammad, G. H. U. L. A. M. (2009): Mastitis control in dairy production. Journal of Agriculture and Social Science, 5, 102-105.

34- Shereen, S.I. (2014): A test of a model basedon measurement of $\mathrm{C}$-reactive protein(CRP) and other parameters in milkand blood. Anovel principle to estimateindividual cow mastitis risk degree. PhD. Thesis, microbiology, Fac. Vet.Med., Cairo Univ.

35- Shrestha, S. and Bindari, Y.R. (2012): Prevalence of Sub-Clinical Mastitis among Dairy Cattle in Bhaktapur District, Nepal. Inter. J. Agri. Biosci., 1(1): 16-19.

36- Srinivasan, P.; Jagadeswaran, D.: Manoharan, R.; Giri, T.; Balasubramaniam, G.A. and Balachandran, P. (2013): Prevalence and Etiology of Subclinieal Mastitis among Buffaloes (Bubalusbubalus) in Namakkal, India . Pakistan Journal of Biological Sciences., 16(23): 1776-1780.
37- Sudhan, N.A., Singh, R., Singh, M. and Soodan, J.S. (2005): Studies on prevalence, etiology and diagnosis of subclinical mastits among crossbred cows. Indian J. Anim. Res., 39 (2): 127 - 130, 2005.

38- Timms L.L.(1990): Can Somatic Cells Get Too Low? In Proceeding $29^{\text {th }}$ Annual Meeting, National Mastitis Council; 94-99.

39- Viguier, C.; Arora, S.; Gilmartin, N.; Welbeck, K. and O'kennedy, R. (2009): Mastitis detection. Current trends and future perspectives. Trend. Biotechnol., 27(8): 486-493.

40- Wilson D.J., Gonzales R.N., Das H.H. (1997): Bovine mastitis pathogens in New York and Pennsylvania: Prevalence and effect on somatic cell count and milk production. J Dairy Sci, 80, 2592-2598.

41- Wilson D.J., Gonzales R.N., Hertl J., Schulte H.F., Bennett G.J., Schukken Y.H., Gröhn Y.T. (2004): Effect of clinical mastitis on the lactation curve; a mixed model estimation using daily milk weights. J Dairy Sci, 87, 2073-2084.

42- Zecconi, A.; Casirani, G.; Binda, E. and Piccinini, R. (2002): The importance of assess the effects of voluntary milking system on teat tissues, intra mammary infections and Somatic Cell Counts, Dept. In Anim. Path.-Infect. Dis. Lab., University of Mailan, Delaval Hygiene, Technology center, Inaugal Symposium. 


\section{العلاقة بين الخلايا الجسدية و التهاب الضرع الكامن لماثية فى الحليب الخام بمصر \\ أميرة حلمى يسن , أحمد عبد الجواد الجمل*", محمد الثربينى * \\ * قسم الرقابة الصحية علي الأغذية - كلية الطب البيطري- جامعة المنصورة \\ ** معهد بحوث صحه الحيوان - المنصورة

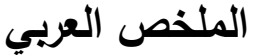

$\% 76, \% 70.7, \% 14.7, \% 50.7, \% 10.7$

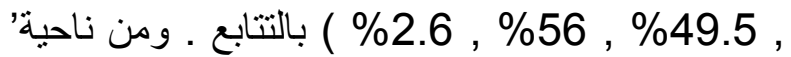

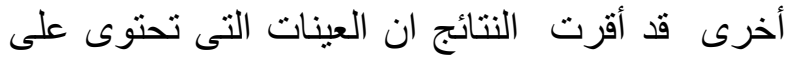

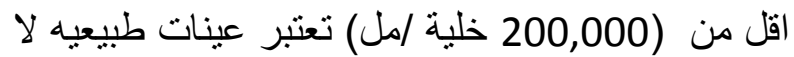

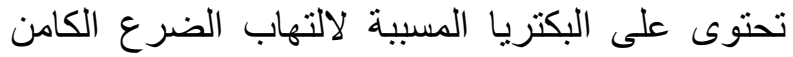

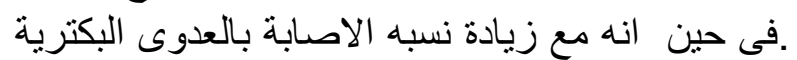

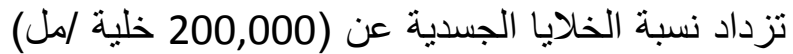

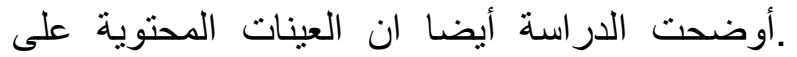

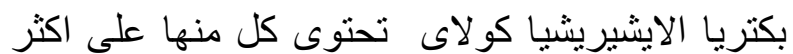

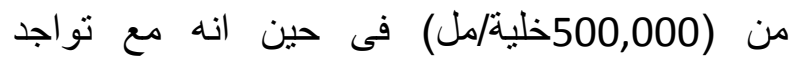

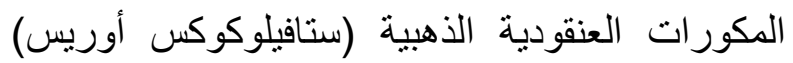
ترتفع النسبه ل (5000,000 خلية /مل)على أقل تقدير القير

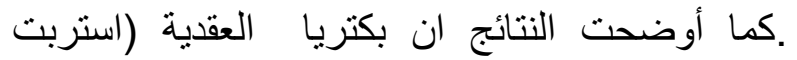

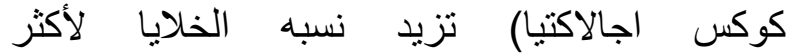

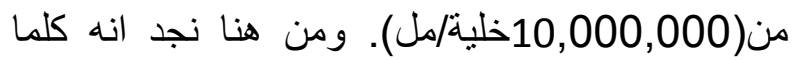
زادت أعداد و انواع البكتريا كلما ارتفعت نسبة الخلايا الجسدية فى الحليب الخام ـ لذا لذا يعتبر قياس الخيا الخلايا

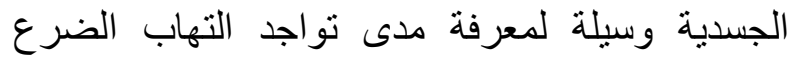

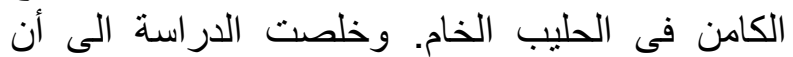

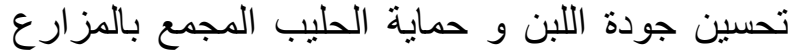

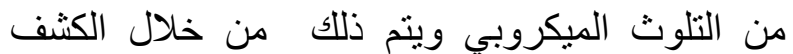

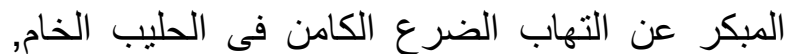

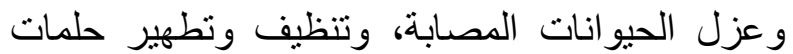
الحيوانات، واستخدام معدات حلب نظيفة وتهيئة بيئة

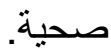

يعتبر فحص الحليب الخام للتأكد من سلامته وجودنه

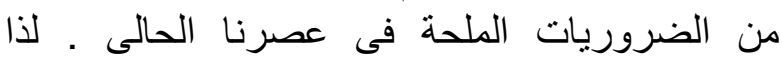

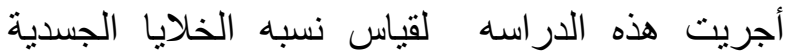

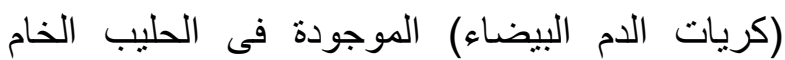

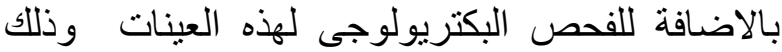

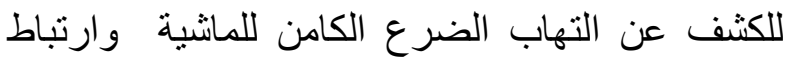

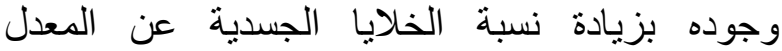
الطبيعى فى عينات اللبن الخام. و قد أجريت الدراسيا

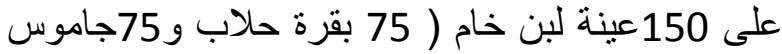

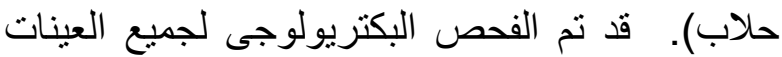

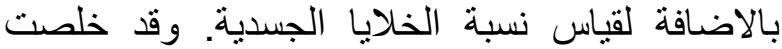
الارراسة ان نسب البكتريا فى عينات الالبان الناتجة من الإن

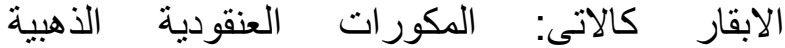

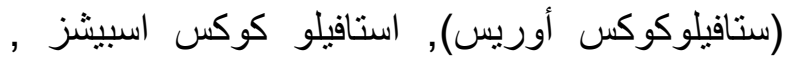

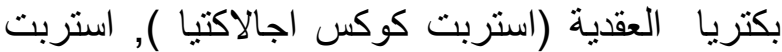

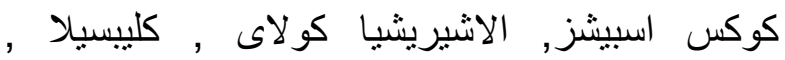
بروتيس , مورجانيلا , بروفيدينشيا بالاضافة الى كائل

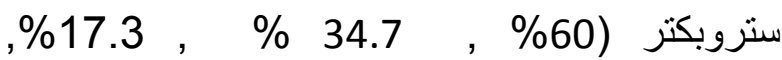
\%24, \%73.3 , \%45.3 , \%18.7, \%54.7 30.7\% , 1.4\%) بالتنابع .أما بالنسبة لنسب البكتريا

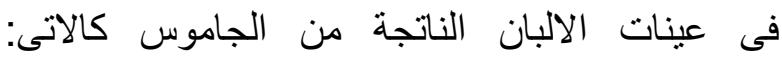
المكورات العنقودية الذهبية (ستافيلوكوكس أوريس), الذبان استافيلو كوكس اسبيشز, بكتريا العقدية ( استربت العبية

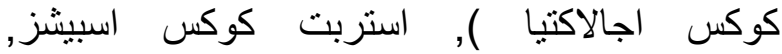

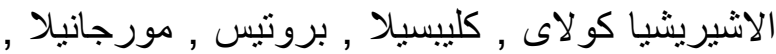
بروفيدينشيا بالاضافة الى ستروبكتر (48\% , 32\% , 